\title{
Dead level contours and infiltration pits for risk mitigation in smallholder cropping systems of southern Zimbabwe
}

\author{
W. Mupangwa ${ }^{\mathrm{a}, \mathrm{b}, *}, \mathrm{~S}$. Twomlow ${ }^{\mathrm{a}, 1}, \mathrm{~S}$. Walker ${ }^{\mathrm{b}}$ \\ ${ }^{a}$ ICRISAT, Matopos Research Station, PO Box 776, Bulawayo, Zimbabwe \\ ${ }^{\mathrm{b}}$ Department of Soil, Crop and Climate Sciences, University of Free State, PO Box 339, Bloemfontein 9300, South Africa
}

\section{A R T I C L E I N F O}

\section{Article history:}

Available online 8 July 2011

\section{Keywords:}

Drought

Dry spells

Seasonal rainfall

Smallholder farming

Soil water dynamics

\begin{abstract}
A B S T R A C T
The persistent droughts, dry spells, and chronic food insecurity in semi-arid areas necessitate the introduction of more robust rainwater harvesting and soil water management technologies. The study reported here was conducted to assess the influence of dead level contours and infiltration pits on in-field soil water dynamics over two growing seasons. A transect consisting of six access tubes, spaced at $5 \mathrm{~m}$ interval, was established across each dead level contour with or without an infiltration pit before the onset of the rains. Two access tubes were installed upslope of the contour while four tubes were installed on the downslope side. Dead level contours with infiltration pits captured more rainwater than dead level contours only resulting in more lateral soil water movement. Significant lateral soil water movement was detected at $3 \mathrm{~m}$ downslope following rainfall events of $60-70 \mathrm{~mm} /$ day. The $0.2-0.6 \mathrm{~m}$ soil layer benefited more from the lateral soil water movement at all the farms. Our results suggest that dead level contours have to be constructed at 3-8 m spacing for crops to benefit from the captured rainwater. It is probably worth exploring strip cropping of food and fodder crops on the downslope of the dead level contours and infiltration pits using the current design of these between-field structures. With the advent of in situ rainwater harvesting techniques included in some conservation agriculture practices it will benefit smallholder cropping systems in semi-arid areas if these between-field structures are promoted concurrently with other sustainable land management systems such as conservation agriculture.
\end{abstract}

(c) 2011 Elsevier Ltd. All rights reserved.

\section{Introduction}

Rainfed crop production plays a pivotal role in the developing countries where the majority of the people depend on agriculture for their livelihoods (Verchot and Cooper, 2008). It is projected that rainfed farming will account for $40 \%$ of growth in cereal production by 2021-2025 (Rosegrant et al., 2002). In the Southern African Development Community (SADC) region human population is growing at $2.4 \%$ per annum while crop output from the smallholder farming sector is declining (Chilonda et al., 2007). The decrease in crop output from the smallholder farming sector is related to climatic and socio-economic constraints faced by households in the region.

Rainfall is the major climatic factor that influences crop production in the smallholder sector under semi-arid environments (Thomas et al., 2007). Rainstorms are often spatially distributed, varying highly even within a few square kilometres (Usman and

\footnotetext{
* Corresponding author at: ICRISAT, Matopos Research Station, PO Box 776, Bulawayo, Zimbabwe. Tel.: +263 773930140 .

E-mail address: mupangwa@yahoo.com (W. Mupangwa).

1 Present address: United Nations Environment Programme, PO Box 30552 (00100), Nairobi, Kenya.
}

Reason, 2004; Love et al., 2008). Temporal rainfall distribution is poor during most growing seasons resulting in soil water deficits at critical stages of crop development. These rainfall characteristics are likely to continue haunting the smallholder agricultural sector of sub-Saharan Africa in the face of climate variability. The African continent has been identified as one part of the world to be hit hard by climate change (Jones and Thornton, 2003).

Rainwater harvesting, a method of collecting surface runoff from a catchment area and storing the water in the root zone of a cultivated area for crop growth (Lie et al., 2004), can play a critical role in reducing production risk in rainfed agriculture. In the semi-arid areas rainwater harvesting could be a source of water for smallholder cropping systems (Falkenmark et al., 2001; Irshad et al., 2007). Traditionally smallholder farmers in Zimbabwe have been using the graded contour ridge for safely diverting excess water from the field (Mutekwa and Kusangaya, 2006). A standard graded contour ridge is pegged at a gradient of $1: 250$ and contour ridges are usually spaced at $20-30 \mathrm{~m}$ apart on gentle slopes (Hughes and Venema, 2005).

Techniques that capture rainwater, reduce surface runoff and promote infiltration have traditionally been used in Africa (Reij et al., 1996). In Africa other rainwater harvesting systems exist such as the Trus system in Sudan, the Zai system in Mali 
and Burkina Faso, and the Tassa system in Niger (Mandiringana et al., 2003). In South Africa extensive research work has been conducted on runoff in-field rainwater harvesting using basins and mulch under semi-arid conditions (Botha et al., 2003) and used by smallholder farmers in marginal areas with maize and a variety of vegetables.

Dead level contours, pegged at zero gradient, are an appropriate between-field technique for harvesting runoff water for crop production. The purpose of a dead level contour is to retain runoff water in the contour hoping that soil water will move into cropped field by lateral flow (Hughes and Venema, 2005). To improve the ability of the dead level contour in retaining runoff, water infiltration pits are dug along the contour often at $10 \mathrm{~m}$ interval and a standard infiltration pit measures $2 \mathrm{~m}$ long, $1 \mathrm{~m}$ wide and $0.5-1$ m deep (Hughes and Venema, 2005).

Efforts by international research organisations, Non-Governmental Organisations (NGOs) and Government Agricultural Departments continue in finding a combination of appropriate technologies that reduce the impact of harsh climatic factors on livelihoods of smallholder farmers. In Gwanda district of southern Zimbabwe dead level contours and infiltration pits are being promoted by Practical Action Southern Africa. The design of the dead level contours includes having an infiltration pit at intervals along the contour. Dead level contours and infiltration pits have been explored in other semi-arid districts of Zimbabwe (Motsi et al., 2004; Mugabe, 2004). Results from these studies have shown that dead level contours and infiltration pits can contribute towards soil water status in the cropped field. In a study by Mugabe (2004) rainwater captured by the infiltration pits replenished soil water on the upslope and downslope sides of the infiltration pit.

Our study in Gwanda district was designed to assess the influence of dead level contours and infiltration pits on soil water patterns on the upslope and downslope sides of dead level contours with or without infiltration pits. The specific objectives of the study were (1) to measure the profile soil water content at 7 and $2 \mathrm{~m}$ upslope, and at 3 and $8 \mathrm{~m}$ downslope of the dead level contours with and without infiltration pits throughout the growing season and (2) to determine the extent to which soil water moves laterally from contours into the cropped field. This paper reports on the soil water changes observed at 2 and $7 \mathrm{~m}$ upslope, and 3 and $8 \mathrm{~m}$ downslope of the dead level contours during 2006/2007 and $2007 / 2008$ growing seasons.

\section{Materials and methods}

\subsection{Site description}

Gwanda district lies in the Mzingwane catchment which is part of the Limpopo river basin and receives annual rainfall of less than $450 \mathrm{~mm}$ (Unganai, 1996; FAO, 2004). Rainfall season is unimodal and begins in November/December and ends in March/April. The cropping season experiences periodic dry spells particularly in January and is followed by a dry season that stretches from May to September. The predominant soils in Gwanda district are coarsegrained sands to loamy sands and clay loams to clay with minor occurrences of vertisols (Anderson et al., 1993). The soils are classified as Eutric/Dystric Regosols and Chromic Luvisols according to FAO/UNESCO classification, and as Ustalfic Haplargid and Lithic/ Ustic Torriorthent according to Soil Taxonomy (Nyamapfene, 1991; FAO, 2004). Landform is almost flat to undulating pediplain with some local hills and rock outcrops. Vegetation consists of Colophospermum mopane as the dominant tree species with scattered associated tree species of Commiphora spp, Combretum apiculatum and Adonsonia digitata. Farming system consists of crop-livestock enterprises and the major crops grown include cereals such as maize (Zea mays L.), sorghum (Sorghum bicolour (L.) Moench) and pearl millet (Pennisetum glaucum (L.) R.Br.) and legumes namely bambara nut (Vigna subterranean $(L)$ Verdc), groundnut (Arachis hypogaea L.) and cowpea (Vigna unguiculata (L.) Walp). The predominant livestock species include cattle (Bos indicus), goats (Capra hircus), donkeys (Equus asinus), chickens (Gallus domesticus) and turkeys (Melleagris gallopavo).

\subsection{Experimental setup}

The experiment was established at four farms located in ward 17 of Gwanda district, southern Zimbabwe. Two farms (Moyo and Ncube) had dead level contours only while the other two (Dube and Siziba) had dead level contours and infiltration pits. The treatments were the rainwater harvesting structure (dead level with or without infiltration pit) $\times$ distance ( 2 and $7 \mathrm{~m}$ upslope; 3 and $8 \mathrm{~m}$ downslope) where soil water measurements were taken and each farm was used as a replicate in this study. Soil water was monitored in PVC access tubes inserted at varying depths depending on the physical characteristics of the soil profile at each farm. In the 2006/2007 growing season a single transect of access tubes was setup across the dead level contours and infiltration pits in conventionally ploughed fields which were under maize, sorghum, pearl millet and groundnut crops. In the 2007/2008 growing season two transects of access tubes, one along conventionally ploughed field and another along unploughed field, were setup at each farm in order to separate the effect of tillage from that of contours on soil water measured at each distance from the contour. The $15 \mathrm{~mm}$ PVC access tubes were installed at 2 and $7 \mathrm{~m}$ from the centre of the dead level contour with or without infiltration pit on the upslope side (Fig. 1). On the downslope side of the dead level contour with or without infiltration pit access tubes were installed at 3 and $8 \mathrm{~m}$ from the centre of the contour. Spacing of access tubes on either side of the dead level contour allowed soil water to be measured up to the middle of the cropped field. The access tubes were inserted to depths varying from 0.5 to $0.8 \mathrm{~m}$ across the four farms. Depth of access tubes was restricted by the presence of a stony layer in the profile at three of the four farms. At each farm access tubes were installed in October and maintained for the subsequent seasons and the donkey-drawn plough was controlled to avoid damaging access tubes during ploughing operations. The dead level contours averaged $0.9-1.0 \mathrm{~m}$ wide and $0.3 \mathrm{~m}$ deep across the four farms. The infiltration pits averaged $1-1.5 \mathrm{~m}$ long, $0.5-1.0 \mathrm{~m}$ wide and $0.3-0.4 \mathrm{~m}$ deep across the two farms (Dube and Siziba). Soil samples were collected between 3 and $8 \mathrm{~m}$ from the contour at $0.15 \mathrm{~m}$ depth interval up to $0.60 \mathrm{~m}$ for texture determination. Soil texture for each farm was determined by

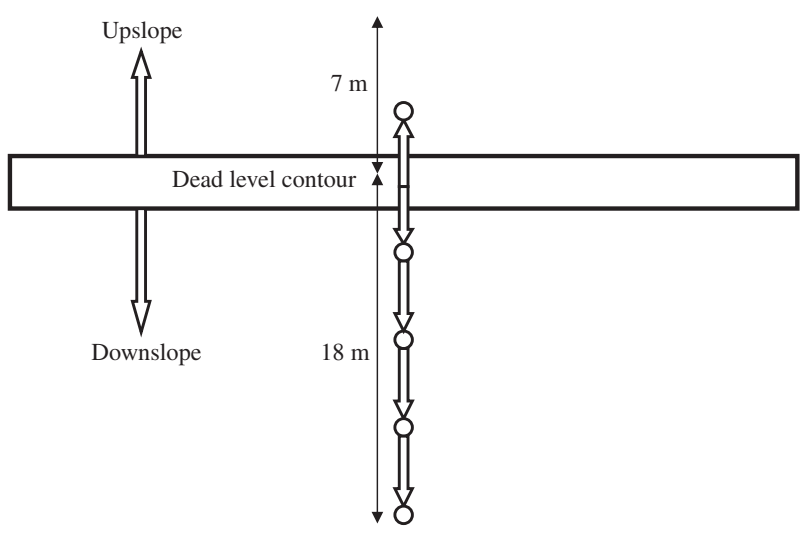

Fig. 1. Schematic diagram of the setup of access tubes across dead level contours at each farm in Gwanda district. 
the hydrometer method as outlined by Anderson and Ingram (1993). Daily rainfall was measured at each farm using a standard manual raingauge.

\subsection{Soil water measurements}

During the 2006/2007 and 2007/2008 growing seasons volumetric soil water content was measured using a capacitance probe (MGPHR microgopher sensor, http://www.odysseydatarecording.com). Soil water was measured every two weeks at $0.1 \mathrm{~m}$ depth intervals during both 2006/2007 and 2007/2008 seasons. Six to eight readings were taken from each access tube depending on the depth of the access tubes. Soil water content in millimetres was determined by multiplying volumetric water content by the thickness of each layer where the soil water was measured. The soil water content in the $0-0.6 \mathrm{~m}$ profile at each farm was calculated during the two growing seasons.

\subsection{Soil water data analysis}

Soil water data were analysed using the method of residual maximum likelihood (REML) (Genstat 9.0 ) because of depth differences achieved during insertion of access tubes on the four farms. The type of dead level contour, distance of soil water measuring point from the contour, depth of soil water measurement, date of soil water measurement, type of tillage around access tubes, and all interactions were included in the fixed model. The farm was included in the random model as a replicate. Each season was analysed separately because of differences in the rainfall patterns experienced during the 2006/2007 and 2007/2008 growing seasons. When the F-test indicated significant differences between means, comparison of means was done using $t$-tests at $5 \%$ significance level.

\section{Results and discussion}

\subsection{Soil physical properties at the four farms}

The physical properties of the soils at the four farms used in this study are summarized in Table 1 . The farms that had a dead level contour with infiltration pits had higher $(P=0.031)$ clay content in

Table 1

Soil physical properties at the four farms used for quantifying soil water supply from dead level contours and infiltration pits in Gwanda district, southern Zimbabwe.

\begin{tabular}{lllccl}
\hline Farm & Contour type & $\begin{array}{l}\text { Depth } \\
(\mathrm{cm})\end{array}$ & $\begin{array}{l}\text { Clay } \\
(\%)\end{array}$ & $\begin{array}{l}\text { Silt } \\
(\%)\end{array}$ & $\begin{array}{l}\text { Sand } \\
(\%)\end{array}$ \\
\hline \multirow{2}{*}{ Moyo } & Only dead level contour & $0-15$ & 5 & 3 & 92 \\
& & $15-30$ & 6 & 4 & 90 \\
& & $30-45$ & 8 & 4 & 88 \\
Ncube & Only dead level contour & $45-60$ & 7 & 8 & 85 \\
& & $0-15$ & 4 & 6 & 90 \\
& & $15-30$ & 3 & 5 & 92 \\
\multirow{5}{*}{ Dube } & $30-45$ & 2 & 8 & 90 \\
& & $45-60$ & 4 & 7 & 89 \\
& Dead level contour and & $0-15$ & 10 & 4 & 86 \\
& infiltration pit & & & & \\
& & $15-30$ & 11 & 3 & 86 \\
\multirow{2}{*}{ Siziba } & Dead level contour and & $30-45$ & 16 & 6 & 78 \\
& infiltration pit & $45-60$ & 18 & 6 & 76 \\
& & $0-15$ & 6 & 13 & 81 \\
& & $15-30$ & 12 & 7 & 81 \\
& & $30-45$ & 18 & 6 & 76 \\
& & $45-60$ & 20 & 7 & 73 \\
\hline
\end{tabular}

the soil profile than those with dead level contours only. The soil types at the four farms ranged from sand to loamy sand.

\subsection{Seasonal rainfall at the farms}

\subsubsection{6/2007 and 2007/2008 growing seasons}

The four farms received different amounts of rainfall during the 2006/2007 growing season (Fig. 2). The number of rainfall events recorded at the four farms ranged from 8 to 17 during the 2006/ 2007 season. The highest daily rainfall event during the 2006/ 2007 season was $38 \mathrm{~mm}$ recorded at Moyo farm on 26 February 2007 (day 149). The total seasonal rainfall recorded during the $2006 / 2007$ growing season ranged from $145 \mathrm{~mm}$ to $242 \mathrm{~mm}$. The total seasonal rainfall recorded at each farm during the 2006/ 2007 season was below the 50 year average of $376 \mathrm{~mm}$ for Beitbridge district (NR V) which has similar climatic characteristics with the southern part of Gwanda district (Mupangwa et al., 2011). A 54-day dry spell was experienced from 2 January 2007 (day 94) to 26 February 2007 (day 149) when $22 \mathrm{~mm}$ of rain was received. The dry spell coincided with the vegetative and flowering stages of the major cereal crops (maize, sorghum and pearl millet) resulting in complete crop failure on most smallholder farms in Gwanda district. Dry spells occurring during the cropping period are a characteristic feature of semi-arid areas of East Africa (Barron et al., 2003), West Africa (Graef and Haigis, 2001) and Southern Africa (Usman and Reason, 2004).

Total seasonal rainfall recorded during the 2007/2008 season ranged from $204 \mathrm{~mm}$ to $298 \mathrm{~mm}$ (Fig. 2). Most of the rainfall events were concentrated in the October-December period with just five events occurring during the January-April period. The highest daily rainfall event was $70 \mathrm{~mm}$ recorded on 8 January (day 100) at Dube, Moyo and Ncube farms. The last rainfall event was recorded on 24 January 2008 (day 116) with $18-20 \mathrm{~mm}$ being received across the four farms. As observed in the 2006/2007 season, total seasonal rainfall at all farms was below $376 \mathrm{~mm}$ which is the 50 year average for Beitbridge district (NR V) of southern Zimbabwe (Mupangwa et al., 2011).
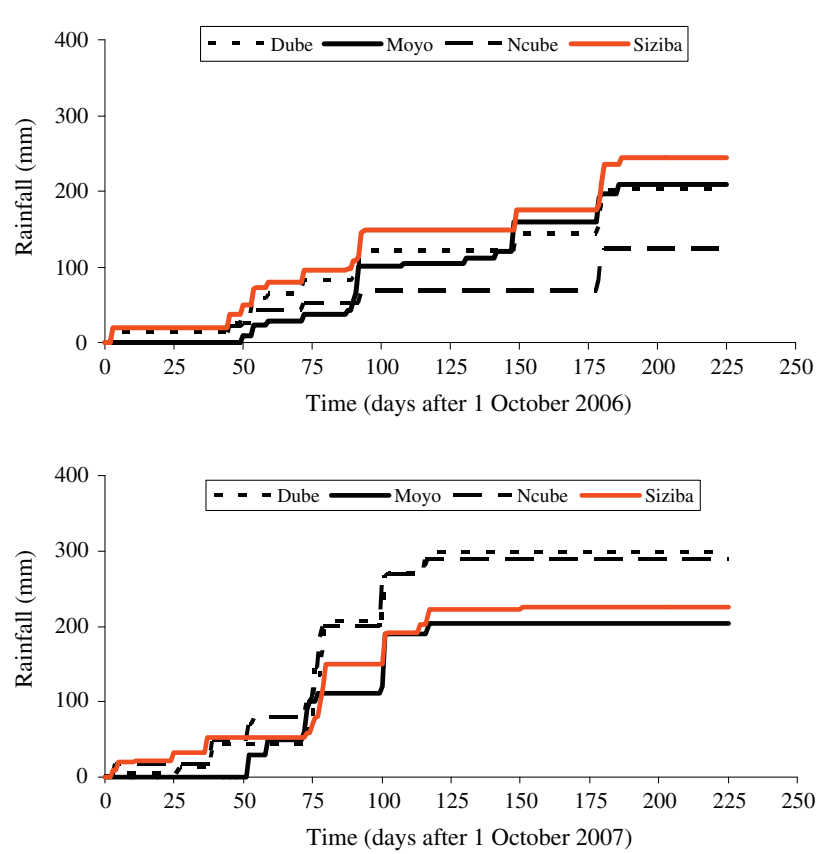

Fig. 2. Daily rainfall distribution at Moyo, Ncube, Dube and Siziba farms of ward 17 in Gwanda district during 2006/2007 and 2007/2008 growing seasons. 


\subsection{Soil water changes in fields with dead level contours only}

\subsubsection{6/2007 growing season}

The distance from the dead level contour had no significant $(P>0.05)$ influence on profile water content recorded along the ploughed transect during the 2006/2007 growing season (Fig. 3). The lowest profile water content was recorded at $7 \mathrm{~m}$ upslope of the dead level contour throughout the season. Soil water content recorded in the profile differed significantly $(P<0.001)$ between the dates when soil water measurements were made indicating the occurrence of wetting and drying cycles during the growing season. This observation was consistent with results from other farms in the same area of Gwanda where in situ rainwater management techniques were being tested (Mupangwa et al., 2008). In the $0-0.60 \mathrm{~m}$ profile, soil water content decreased by $52-53 \%$ upslope of the dead level contour and $49-51 \%$ downslope of the contour between days 117 and 142 . A $7 \mathrm{~mm}$ rainfall event was recorded at Moyo farm between 25 January (day 117) and 19 February (day 142 ) and this amount was negligible to cause any notable changes in profile soil water content. The soil profiles at Moyo and Ncube farms were recharged by $49-57 \mathrm{~mm}$ of rain that was received between 28 March (days 179) and 13 April (194) (Figs. 2 and 3).

On 12 January 2007 (day 104), the wettest day when soil water measurements were made, there was no significant difference $(P>0.05)$ in soil water content measured at each depth at all the distances from the dead level contour along the ploughed transect (Fig. 4). The $0-0.15 \mathrm{~m}$ layer had more $(P<0.001)$ soil water than the deeper layers at each distance from the dead level contour (Fig. 4). There was higher soil water content at $8 \mathrm{~m}$ from the dead level contour than other distances suggesting the contribution of conventional ploughing to the measured soil water. In the top $0.5 \mathrm{~m}$ soil layer the lowest soil water content was recorded at

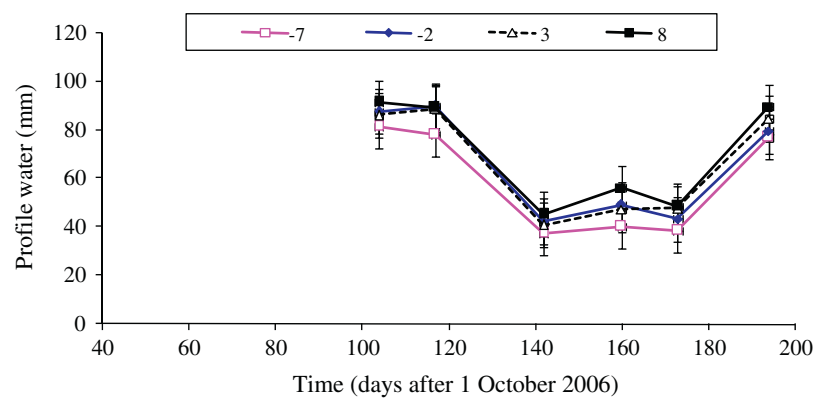

Fig. 3. Profile soil water changes along ploughed transects averaged across two farms with dead level contours only (Moyo and Ncube) during the 2006/2007 growing season. Vertical bars represent standard error.

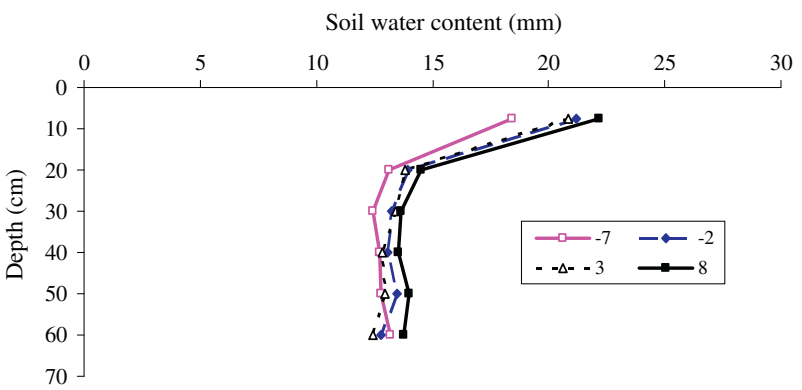

Fig. 4. Soil water distribution with respect to depth at different distances from the dead level contour only averaged across two farms (Moyo and Ncube) on the wettest day (12 January 2007) along ploughed transect during 2006/2007 growing season.
$7 \mathrm{~m}$ upslope of the contour, further confirming negligible lateral movement of soil water from the dead level contour.

\subsubsection{7/2008 growing season}

There was no significant $(P>0.05)$ difference in profile water content recorded along the unploughed and ploughed transects between 14 November 2007 (day 45) and 9 January 2008 (day 101) (Fig. 5). After receiving $70 \mathrm{~mm}$ of rain on 8 January 2008, the measured profile water content at $8 \mathrm{~m}$ was $15 \%$ less than at $3 \mathrm{~m}$ downslope along the unploughed transect. On the upslope side of the contour, the recorded profile water content at $2 \mathrm{~m}$ was $14 \%$ less than at $3 \mathrm{~m}$. There was $20 \%$ more soil water in the profile at $3 \mathrm{~m}$ downslope than at $7 \mathrm{~m}$ upslope. After receiving $70 \mathrm{~mm}$ of rain, the highest profile water content along the ploughed transect was recorded at $3 \mathrm{~m}$ downslope, suggesting that water had moved laterally from the dead level contour. Conventional ploughing further increased profile water content along the ploughed transect. Ploughing loosens the soil and creates surface depressions that collect rainwater giving it more time to infiltrate (Van der Meer, 2000; Sasal et al., 2006).

Along the unploughed and ploughed transects the $0-0.15 \mathrm{~m}$ soil layer had significantly $(P<0.001)$ higher soil water content than the deeper layers at each distance from the contour following the $70 \mathrm{~mm}$ rainfall event (Fig. 6). The distance from the dead level contour had a significant $(P<0.001)$ influence on soil water content measured at each depth along the unploughed and ploughed transects after the $70 \mathrm{~mm}$ rainfall event. The highest soil water content at each soil depth was recorded at $3 \mathrm{~m}$ along the unploughed transect (Fig. 6). Along the ploughed transect, soil layers below $0.2 \mathrm{~m}$ depth were wettest at $3 \mathrm{~m}$ (Fig. 6). This further confirms that there was lateral soil water movement following the $70 \mathrm{~mm}$ rainfall event along both the unploughed and ploughed transects. There was better lateral soil water movement between 0.3 and $0.4 \mathrm{~m}$ depths along the ploughed transect. This could be attributed to the influence of soil physical properties on the lateral movement of water in the profile. The $0-0.15 \mathrm{~m}$ soil layer had more soil water at 2,7 and $8 \mathrm{~m}$ than at $3 \mathrm{~m}$ from the contour, confirming the contribution of conventional tillage on the soil water content measured along the ploughed transect.
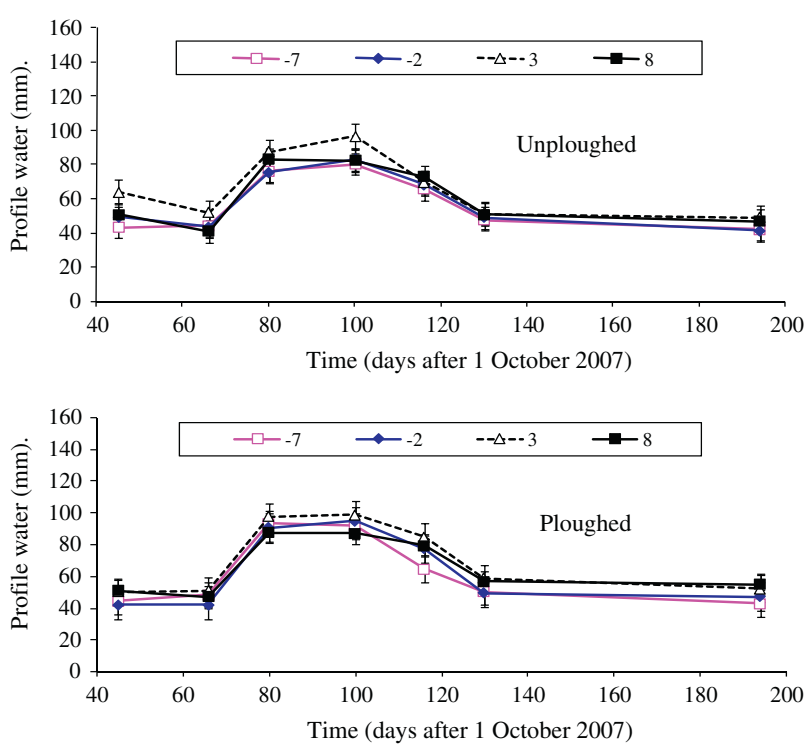

Fig. 5. Profile soil water changes averaged across two farms (Moyo and Ncube) with dead level contours only along unploughed and ploughed transects during 2007/ 2008 growing season. Vertical bars represent standard error. 

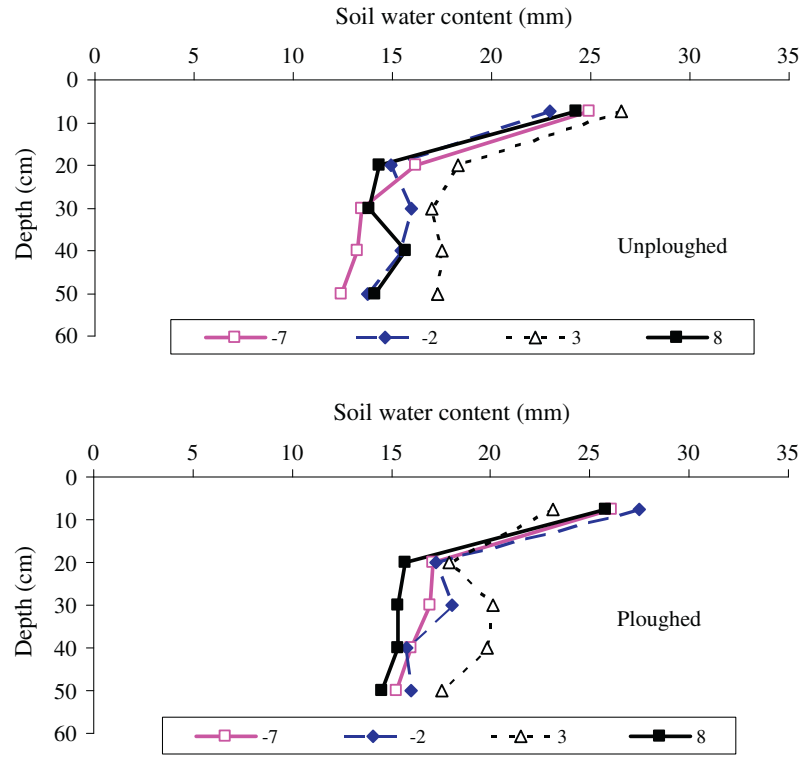

Fig. 6. Soil water distribution with respect to depth at different distances from the dead level contour only averaged across two farms (Moyo and Ncube) on wettest day along unploughed and ploughed transects during 2007/2008 growing season.

\subsection{Farms with dead level contours and infiltration pits}

\subsubsection{6/2007 growing season}

As observed at farms with dead level contours only, distance from the contour had no significant $(P>0.05)$ influence on profile soil water content measured on each day soil water measurements were taken (Fig. 7). Profile water content decreased significantly $(P<0.001)$ between 25 January (day 117$)$ and 19 February (day 142 ) at all distances from the dead level contour and infiltration pit. Profile water content decreased by $52 \%$ to $54 \%$ upslope of the contour and $51 \%$ downslope of the dead level contour and infiltration pit. The soil profiles at the two farms were recharged following 22 and $26 \mathrm{~mm}$ of rainfall recorded on 24 February (day 149) (Fig. 2). The rainfall events that occurred between 28 March (day 179) and 13 April (day 194) also recharged the soil profiles at Dube and Siziba farms. Dube farm received $60 \mathrm{~mm}$ of rain over a nine day period while Siziba farm accumulated $69 \mathrm{~mm}$ during the same period (Fig. 2).

Soil water distribution with respect to depth measured on the wettest day (12 January) during the 2006/2007 season is given in Fig. 8. The top layer had more $(P<0.001)$ soil water than the deeper layers on 12 January, 9 days after a $35 \mathrm{~mm}$ rainfall event. The $0-0.15 \mathrm{~m}$ soil layer had more soil water at $2 \mathrm{~m}$ upslope on 12 January (day 104) than at the other distances 9 days after the last rainfall event. The higher soil water content in the top layer at $2 \mathrm{~m}$

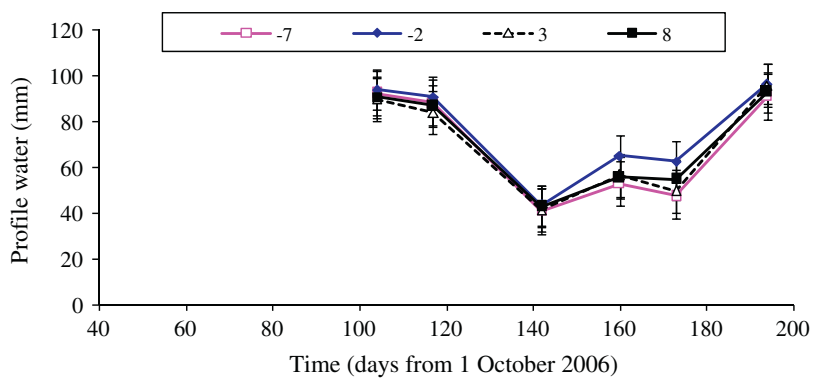

Fig. 7. Profile soil water changes at different distances from the dead level contour with infiltration pit averaged across two farms (Dube and Siziba) during 2006/2007 growing season. Vertical bars represent standard error.

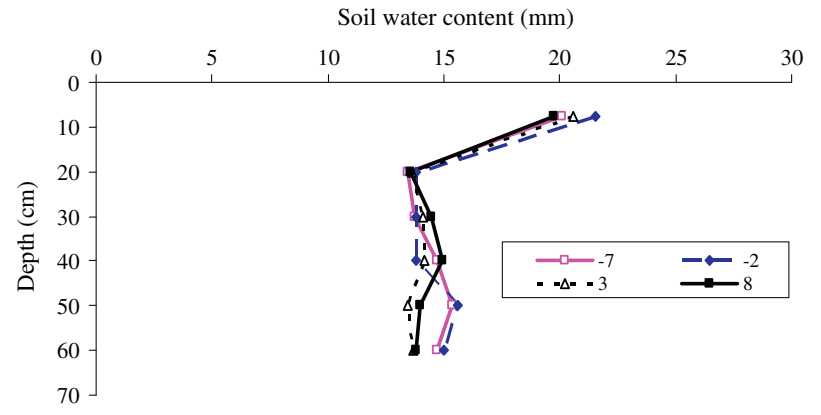

Fig. 8. Soil water distribution with respect to depth at different distances from the dead level contour and infiltration pits averaged across two farms (Dube and Siziba) on wettest day during 2006/2007 season.

upslope can be attributed to the fact that more rainwater was captured in the surface depressions around the access tube since the transect was conventionally ploughed.

\subsubsection{7/2008 growing season}

The soil profile along the ploughed transect had more soil water than the unploughed transect. The unploughed transect had the highest profile water content at $8 \mathrm{~m}$ from the contour after receiving $60 \mathrm{~mm}$ of rainfall on 8 January 2008 (Fig. 9). There could have been some surface depressions near the access tube at $8 \mathrm{~m}$ that were created by conventional ploughing in previous seasons. These depressions collected rainwater during the rainfall event of 8 January (day 100) resulting in the higher soil water observed than at the other distances from the contour. Contrary to the ploughed transect, the lowest soil water content along the unploughed transect on 9 January 2008 was recorded at $7 \mathrm{~m}$ upslope. Profile soil water content at $7 \mathrm{~m}$ upslope was $5 \%$ less than at $2 \mathrm{~m}$ upslope and $8 \%$ less than at 3 and $8 \mathrm{~m}$ downslope along the unploughed transect. Along the ploughed transect the highest soil water content in the profile was recorded at $3 \mathrm{~m}$ between 14 November 2007 (day 45) and 12 April 2008 (day 194) (Fig. 9). Following the
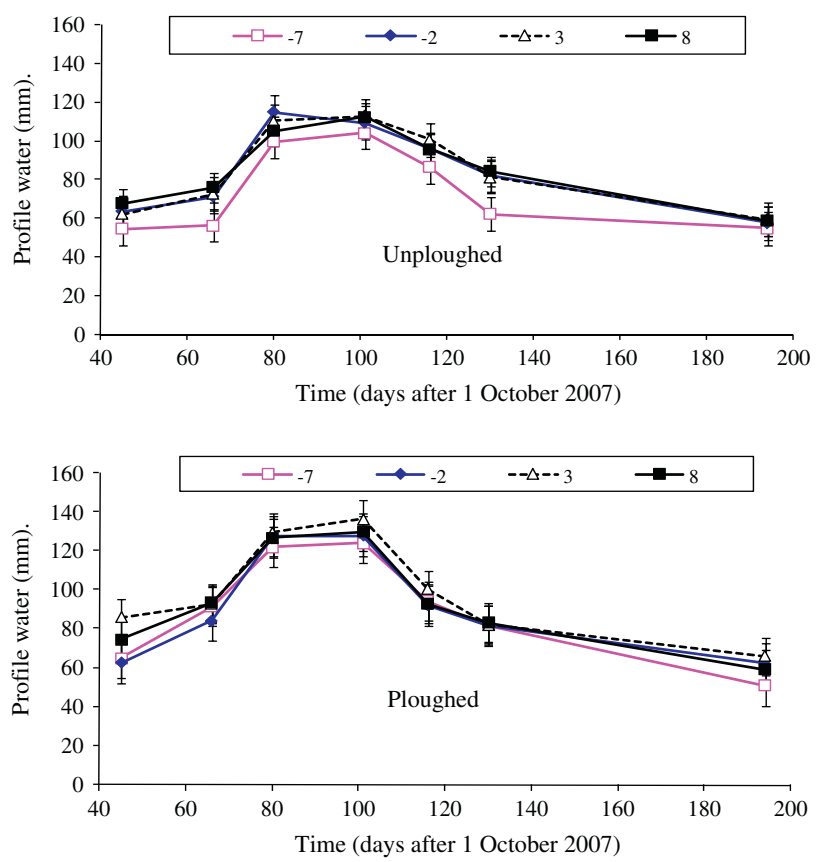

Fig. 9. Profile soil water changes along unploughed and ploughed transects at farms with dead level contours and infiltration pits averaged across two farms (Dube and Siziba) during 2007/2008 growing season. Vertical bars represent standard error. 

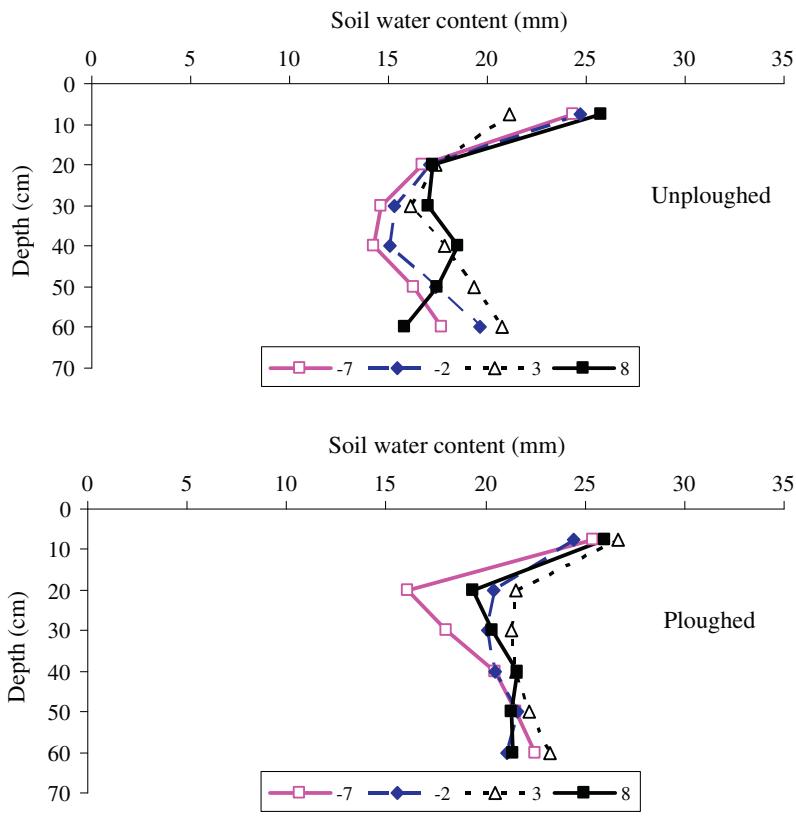

Fig. 10. Soil water distribution with respect to depth at different distances from the dead level contour and infiltration pits averaged across two farms (Dube and Siziba) on wettest day along unploughed and ploughed transects during 2007/2008 season.

$70 \mathrm{~mm}$ rainfall event of 8 January 2008, profile soil water content recorded at $3 \mathrm{~m}$ downslope was $7 \%$ and 10\% more than at 2 and $7 \mathrm{~m}$ upslope, and 5\% more than at $8 \mathrm{~m}$ downslope.

On 9 January 2008 (day 101) the soil profile along the ploughed transect had more $(P<0.001)$ water than the unploughed transect (Fig. 10). This indicates that conventional ploughing increased soil water content through collecting rainwater in the surface depressions created during the tillage operation. The distance from the dead level contour and infiltration pit had no significant $(P>0.05)$ influence on soil water content measured at each soil depth along the unploughed transect throughout the 2007/2008 growing season (Fig. 10). The $0-0.15 \mathrm{~m}$ soil layer had higher $(P<0.05)$ soil water content than the deeper layers along the unploughed and ploughed transects (Fig. 10). Along the ploughed transect the wettest $0-0.15 \mathrm{~m}$ layer was at $3 \mathrm{~m}$ while the same layer was driest at $2 \mathrm{~m}$ upslope (Fig. 10). More profile water was gained downslope at farms with dead level contours and infiltration pits than at those farms with dead level contours only following the $60-70 \mathrm{~mm}$ rainfall event (Fig. 6 and 10). This indicates that the dead level contours and infiltration pits at Dube and Siziba farms captured more rainwater that moved laterally into the field than the dead level contours at Moyo and Ncube farms. Our observation at Dube and Siziba farms are consistent with the findings of Mugabe (2004) that also indicated lateral soil water movement upslope and downslope of an infiltration pit measuring $7 \mathrm{~m}$ long and $1 \mathrm{~m}$ deep.

\section{Conclusion}

As expected the upward side of the dead level contour with or without infiltration pit was drier than downslope on most occasions when soil water was measured. The dead level contours with infiltration pits captured more rainwater following heavy rainfall events $(60-70 \mathrm{~mm})$. After the contours and infiltration pits had filled with rainwater following rainfall events of 60 and $70 \mathrm{~mm}$ on 8 January 2008, the wettest parts of the field were at -2 and $3 \mathrm{~m}$ from the contour. The soil layers that benefited most from the rainwater captured by the dead level contours with/without infiltration pit were in the middle $(0.2-0.5 \mathrm{~m})$ of the $0-0.6 \mathrm{~m}$ soil profile. Crops such as maize, sorghum, pearl millet and legumes commonly grown in semi-arid areas can access soil water from these soil layers. The bulk of the active maize roots have been observed in the $0-0.8 \mathrm{~m}$ soil layer (Amato and Ritchie, 2002) although roots can reach $1.5 \mathrm{~m}$ deep depending on the soil type. For sorghum and pearl millet most of the roots are concentrated in 0$0.50 \mathrm{~m}$ soil layer (Zaongo et al., 1997). Roots for grain legumes such as cowpea are also concentrated in the $0-0.50 \mathrm{~m}$ soil layer (Moroke et al., 2005).

Results from this study suggest that the dead level contours have to be constructed between 3 and $8 \mathrm{~m}$ spacing if they are to supply soil water to crops in the field. However, given the labour and time requirements for the construction of these structures and the limited soil water benefits observed so far, it is not worthwhile investing in these rainwater harvesting structures using the current design in areas such as Gwanda district with a $<1 \%$ slope and light textured soils. There are limited or unclear short term benefits (e.g. grain for human consumption and stover for livestock feeding) derived from the labour, equipment such as shovels, picks and wheelbarrows, and time invested in constructing dead level contours and infiltration pits on smallholder farms in Gwanda district. Low producer prices for small grains (<US\$250/tonne), poor marketing and transport systems leave smallholder farmers in Gwanda with no incentive to invest in the construction and maintenance of the dead level contours on their farms. The labour constraint is further exacerbated by the migration of able-bodied household members to urban centres or South Africa and Botswana in search of employment and better life. Most of the farming activities are therefore left in the hands of the elderly, women and children. Socio-economic studies should be conducted to assess the viability of these rainwater harvesting structures in a farming system that faces persistent labour constraints.

Given the crop-livestock systems of Gwanda district, it is probably worth exploring strip cropping of food and fodder crops on the downslope side of the dead level contours and infiltration pits. Deep rooted fodder crops or drought tolerant agroforestry tree species would benefit more from the soil water supply derived from dead level contours and infiltration pits. Combining structures such as dead level contours and infiltration pits with in situ rainwater management techniques such as planting basins, tine ripping and mulching could be explored to assess if it will bring better returns to smallholder farms where dead level contours and infiltration pits are being promoted and used. New designs of dead level contours and infiltration pits for different soil types and slopes could be explored as a way forward in the use of inter-field rainwater harvesting structures. Future studies could also focus on determining the rainfall threshold that would make dead level contours with and without infiltration pits, as well as infiltration pits only effective rainwater harvesting technique for semi-arid cropping systems.

\section{Acknowledgements}

This paper is a contribution to WaterNet Challenge Program Project 17 'Intergrated Water Resource Management for Improved Rural Livelihoods: Managing risk, mitigating drought and improving water productivity in the water scarce Limpopo Basin'. The cooperation of farmers in ward 17 of Gwanda district and field officers from Practical Action for southern Africa is gratefully acknowledged.

\section{References}

Amato, M., Ritchie, J.T., 2002. Spatial distribution of roots and water uptake of maize (Zea mays L.) as affected by soil structure. Crop Science 42, 773-780. 
Anderson, I.P., Brinn, P.J., Moyo, M., Nyamwanza, B., 1993. Physical Resource Inventory of Communal Lands of Zimbabwe. Natural Resources Institute Bulletin 60, London.

Anderson, J.M., Ingram, J.S.I., 1993. Tropical soil biology and fertility,... A Handbook of Methods, second ed. C.A.B. International, Wallingford, UK.

Barron, J., Rockström, J., Gichuki, F., Hatibu, N., 2003. Dry spell analysis and maize yields for two semi-arid locations in east Africa. Agriculture and Forest Meteorology 117, 23-37.

Botha, J.J., van Rensberg, L.D., Anderson, J.J., Hensley, M., Macheli, M.S., van Staden, P.P., Kundhlande, G., Groenewald, D.G., Baiphethi, M.N. 2003. Water conservation technologies on small plots in semi-arid areas to enhance rainfall use efficiency, food security and sustainable crop production. WRC Report No. 1176/1/03. 338pp.

Chilonda, P., Machethe, C., Minde, I., 2007. Poverty, food security and agricultural trends in Southern Africa. Regional Strategic Analysis and Knowledge Support System for Southern Africa (ReSAKSS-SA), Discussion Paper No. 1. ReSAKSS-SA, IWMI and ICRISAT, Pretoria, South Africa. 40pp.

Falkenmark, M., Fox, P., Persson, G., Rockström, J., 2001. Water Harvesting for Upgrading of Rainfed Agriculture-Problem Analysis and Research Needs. SIWI Report No11. Stockholm International Water Institute, Stockholm, Sweden, 94pp..

FAO, 2004. Drought impact mitigation and prevention in the Limpopo River Basin. Land and Water Discussion Paper 4. Food and Agriculture Organisation of the United Nations, Rome. <http://www.fao.org/docrep/008/y5744e/ y5744e00.HTM>.

Graef, F., Haigis, J., 2001. Spatial and temporal rainfall variability in the Sahel and its effects on farmers' management strategies. Journal of Arid Environments 48, 111.

Hughes, O., Venema, J.H. (Eds.), 2005. Intergrated soil, water and fertility management in semi-arid Zimbabwe. Farmer Field Schools Manual, vol. 1. Harare, Zimbabwe: FAO. <ftp://ftp.fao.org/agl/agll/docs/ffsfm_zim.pdf>.

Irshad, M., Inoue, M., Ashraf, M., Al-Busaidi, A., 2007. The management options of water for the development of agriculture in dry areas. Journal of Applied Sciences 7 (11), 1551-1557.

Jones, P.G., Thornton, P.K., 2003. The potential impacts of climate change on maize production in Africa and Latin America in 2055. Global Environmental Change $13,51-59$.

Lie, X.K., Xie, Z.K., Yan, X.K., 2004. Runoff characteristics of artificial catchment materials for rainwater harvesting in the semi-arid regions of China. Agricultural Water Management 65, 211-224.

Love, D., Uhlenbrook, S., Twomlow, S., van der Zaag, P., 2008. Changing rainfall and discharge patterns in the northern Limpopo Basin, Zimbabwe. Water SA 36 (3), 335-350.

Mandiringana, O.T., Mabi, M., Simalenga, T.E. 2003. The potential of three water conservation technologies for adoption and use by communal farmers in Eastern Cape. In: Beukes, D., de Villiers, M., Mkhize, S., Sally, H. and van
Rensberg, L. (Eds.). Proceedings of the Symposium and Workshop on Water Conservation Technologies for Sustainable Dryland Agriculture in sub-Saharan Africa. Bloemfontein, South Africa. 8-11 April 2003. pp. 56-59.

Moroke, T.S., Schwartz, R.C., Brown, K.W., Juo, A.S.R., 2005. Soil water depletion and root distribution of three dryland crops. Soil Science Society of America Journal 69, 197-205.

Motsi, K.E., Chuma, E., Mukamuri, B.B., 2004. Rainwater harvesting for sustainable agriculture in communal lands of Zimbabwe. Physics and Chemistry of the Earth 29, 1069-1073.

Mugabe, F., 2004. Evaluation of the benefits of infiltration pits on soil moisture in semi-arid Zimbabwe. Journal of Agronomy 3, 188-190.

Mupangwa, W., Twomlow, S., Walker, S., 2008. The influence of conservation tillage methods on soil water regimes in semi-arid southern Zimbabwe. Physics and Chemistry of the Earth 33, 762-767.

Mupangwa, W., Walker, S., Twomlow. S. 2011. Start, end and dry spells of the growing season in semi-arid southern Zimbabwe. Journal of Arid Environment, doi: 10.1016/j.jaridenv.2011.05.011.

Mutekwa, V., Kusangaya, S., 2006. Contribution of rainwater harvesting technologies to rural livelihoods in Zimbabwe: The case of Ngundu ward in Chivi district. Water SA 32 (2), 437-444.

Nyamapfene, K., 1991. Soils of Zimbabwe. NeHanda Publishers, Harare, Zimbabwe, 179pp..

Rosegrant, M., Cai, X., Cline, S., Nakagawa, N., 2002. The role of rainfed agriculture in the future of global food production. ETPD Discussion Paper No. 90 Environment and Production Technology Division, International Food Policy Research Institute, Washington, DC 20006, USA. February 2002.

Reij, C., Scoones, I., Toulmin, C., 1996. Sustaining the Soil: Indigenous Soil and Water Conservation in Africa. Earthscan Publications Ltd., London, 260pp..

Sasal, M.C., Andriulo, A.E., Taboada, M.A., 2006. Soil porosity characteristics and water movement under zero tillage in silty soils in Argentinean Pampas. Soil and Tillage Research 87, 9-18.

Thomas, D.S.G., Twyman, C., Osbahr, H., Hewitson, B., 2007. Adaptation to climate change and variability: farmer responses to intra-seasonal precipitation trends in South Africa. Climate change 83, 301-322.

Unganai, S.L., 1996. Historic and future climatic changes in Zimbabwe. Climate Research 6, 137-145.

Usman, M.T., Reason, C.J.C., 2004. Dry spell frequencies and their variability over southern Africa. Climate Research 26, 199-211.

Van der Meer, F.W., 2000. Modeling tropical soil water regimes in semi-arid environments. Ph.D. Thesis, Loughborough University. 270pp.

Verchot, L.V., Cooper, P., 2008. International agricultural research and climate change: A focus on tropical systems. Agriculture, Ecosystems and Environment $126,1-3$

Zaongo, C.G.L., Wendt, C.W., Lascano, R.J., Juo, A.S.R., 1997. Interactions of water, mulch and nitrogen on sorghum in Niger. Plant and Soil 197, 119-126. 